\title{
Influence of Calcium on Insulin Secretion in Newborns
}

\author{
E. Heinze ${ }^{[14]}$, R. Fussgänger, and W. M. Teller \\ Department of Pediatrics, Division of Endocrinology and Metabolism, Center of Internal Medicine and Pediatrics, \\ University of Ulm/Donau, Federal Republic of Germany
}

\section{Extract}

The effect of calcium and of glucose on insulin secretion was evaluated in neonates. Calcium evoked a prompt and highly significant insulin output, whereas glucose was a poor stimulus.

\section{Speculation}

The fact that calcium stimulated insulin release suggests that in neonates the microtubulus-microfilament system in the $\beta$-cell is fully developed. In contrast, the glucosemediated mechanisms for insulin release seem to function only partially. 


\section{Introduction}

Recent investigations focus on the important role of calcium for the insulin secreting mechanisms (2). It has already been shown that glucose is a poor stimulus for the release of insulin in the newborn $(5,13)$. Therefore the effect of calcium on the secretion of insulin was studied during the first days of life. It was compared with the effect of glucose. All tests were performed during exchange transfusions with ACD-blood, because the infusion of large doses of calcium is a common practice in this situation and the umbilical vein catheter allows easy blood sampling.

\section{Materials and Methods}

The patient material consisted of 8 newborns (5 girls and 3 boys with a birth weight $1720 \mathrm{~g}$ and $3700 \mathrm{~g})$.

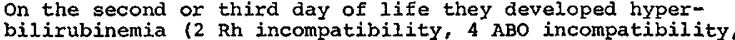
2 idiopathic hyperbilixubinemia).

The effect of calcium on insulin secretion was studied during exchange transfusions with ACD-blood via the umbilical vein. The glucose concentration in the preserved blood was approximately $300 \mathrm{mg}$. For each $100 \mathrm{ml}$ exchanged blood, $2 \mathrm{ml}$ of calcium gluconate. solution ( $10 \%$ ) were injected as a pulse; in addition, some newborns received $0,33 \mathrm{~g} / \mathrm{kg}$ bodyweight of glucos as a $20 \%$ solution following $160 \mathrm{ml}$ or $260 \mathrm{ml}$ of ex changed blood. Before the injections, after 1 min. and 3 min. serum glucose, calcium and immoreactive insulin were determined. Glucose was measured with the ferricyanide method adjusted for the autoanalyser, by radioimmunots accin (8). cy radioimmunoassay according to MELANI et al. (8).

\section{Results}

In the eight newborns 19 calcium injections were performed. According to glucose level's the results were divided into group $A(n=8)$ and group $B(n=11)$ In group $A$ the glucose concentration before the injection of calcium was below $110 \mathrm{mg}$, while in group ficantly rose to almost identical levels at 1 and 3 minutes after the injection, while glucose decreased at the same time (figure 1 ). This decrease was only significant in group $A$. Insulin increased in both groups with a peak at i min. following the injection of calcium. In group $B$ the insulin concentration was much higher than in group $A$.

Contrasting to above findings glucose injections stimulated $(n=5)$ the secretion of insulin in three out of five newborns tested. The mean value of insulin levels in these 5 expeximents did not change significantly (table 1).

\section{Discussion}

Metabolic and hormonal changes have been reported during exchange transfusions with ACD-blood (9). Citrate stimulates insulin secretion in vitro $(10)$ and the higher insulin concentration at $0 \mathrm{~min}$. ( $\mathrm{fig} .1$, and tab. 1) compared to the fasting state, might be the result of the citrate load infused with the donor blood. In the present study the role of citrate was not in vestigated, but it may be assumed, that at 1 and 3 , the minutes after the injection of calcium or glucose, the blood was infused during this short period. In addition blood was infused during this short period. In direct measurements of citrate in the islets of concept that this substrate plays a key role in the insulin secretion (4).
The results reported show that in the newborn calcium is a potent stimulus for the secretion of insulin. Furthermore, the action of calcium is glucose dependent since at higher glucose concentrations far more insulin is released than at glucose concentrations in the normal range. As has been reported for adult in the B-cell (7), which in turn triggers insulin release by interacting with the microtubular microfilament system (6). Since calcium stimulated insulin secretion in ali newborns tested, our results indicate that the mechanisms for insulin release connected with the microtubular microfilament systems are fully developed at this age.

In contrast to calcium, glucose was a poor stimulus for insulin release, as has previously been shown (1, 12, 13). In two out of five newborns, it had no effect. Why glucose is such a poor stimulus shortly after birth is only partially known. One reason might be the difference in glucose metabolism in newborn and adult islets of Langerhans (3). Another factor could be the glucose concentration during intrauterine life, since it is well known that in infants of diabetic mothers glucose significantly stimulates insulin secretion $(5,11)$.

\section{References and Notes}

1. Grasso, S., Messina, A., Saporito, N., Reitano, G. insulin response to glucose and aminoacids in the premature infant. Lancet, $\underline{2}, 755$ (1968).

2. Grodsky, G.M.: The threshold distribution hypothesis for packet storage of insulin. II. Effect of calcium. Diabetes, 21 (Suppl. 2), 584 (1972).

3. Heinze, E., Steinke, J.: Glucose metabolism of isoated pancreatic islets: Differences between fetal,

4. Hellman, B., Idahl, M.K.: Pancreatic islet levels of citrate under conditions of stimulated and inhibited insulin release. Diabetes, 21, 999 (i972).

5. Jorgensen, K.R., Deckert, T., Petersen, L.M., Petersen, M.: Insulin, insulin antibody and glucose in plasma of newborn infants of diabetic women. Act. endocrinol., 52, 154 (1966).

6. Malaisse, W.I., Malaisse-Iagae, F., Brisson, G.: The stimulus-secretion coupling of glucose-induced li earth cations. Horm. Metab. Res. 3,65 (1970). 7. Malaisse, W.I., Malaisse-Lagae, F.: A possible role for
calcium in the stimulus-secretion coupling for glucoseinduced insulin secretion. Acta Diabet. Lat., 7 (Suppl.), 264 (1970).

8. Melani, R., Ditschuneit, H., Bartelt, K.M., Friedrich, H., Pfeiffer, E.F.: Uber die radioimmunologische Bestimmung von Insulin im Blut. Klin. Wschr., 43, 1000 (1965).

9. Milner, R.D.G., Fekete, M., Assan, R.: Glucagon, insulin and growth hormone response to exchange transfusions in premature and term infants. Arch. Dis. Child. 47, 186 (1972).

10. Montague, W., Taylor, K.W.: Islet-cell metabolism during insulin release. Effects of glucose, citrate, octanate, tolbutamide, glucagon and theophylline. Biochem. J., 115, 257 (1969).

11. Pedersen, I., Pedersen, M., Jorgensen, K.J.: Insulin and glucose in plasma form umbilical vein and heel blood of newborn

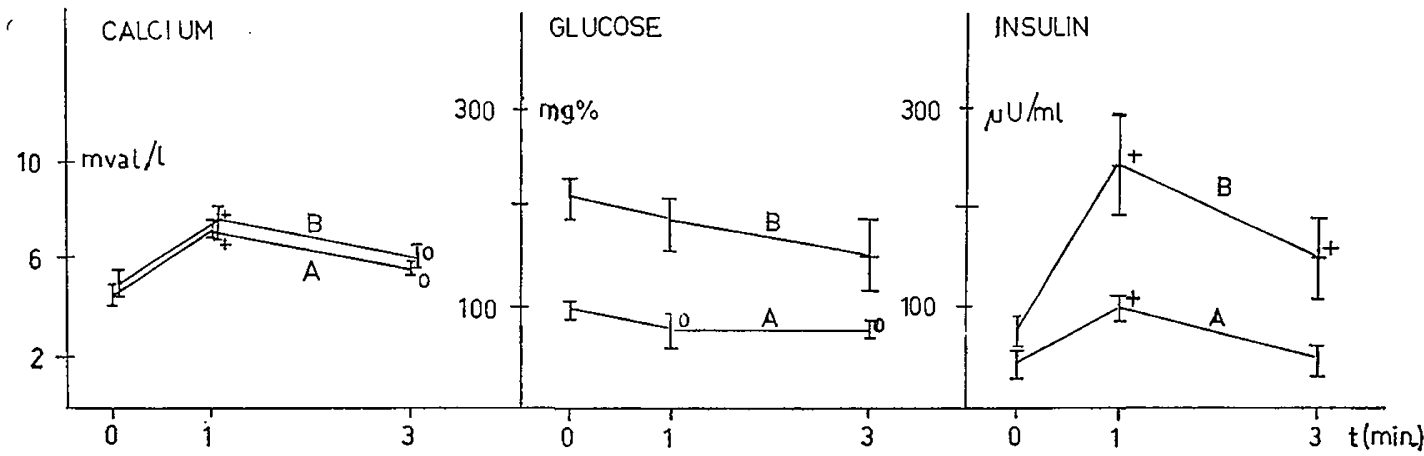

Figure 1: Effect of calcium, $2 \mathrm{ml} 10 \%$ calcium gluconate i.v., on serum calcium,glucose and insulin. $0_{p}<0.05 ; t_{p}<0.005$ compared to 0 minutes. All other values are not significant. $\left(M_{0} \pm\right.$ S.E. $\left.M_{0}\right)$ 
12. Piledes, R.S., Hart, R., Warner, R., Cornblath, M.: Plasma insulin response during oral glucose tolerance tests in newborns of normal and gestat
mothers. Pediatrics, 44,76 (1969).

13. Tobbin, J.D., Roux, J.F., Soeldner, J.S.: Human fetal insulin response aftex acute maternal glucose admini stration during labor. Pediatrics. 44, 668 (1969).

14. Requests for reprints should be addressed to: Dr. E. Heinze, Department of Pediatrics, University of Ulm/Donau, $79 \mathrm{U} 2 \mathrm{~m}$, Prittwitzstr. 43, Fed.Rep.Germany

15. Accepted for publication December 10, 1972.

\begin{tabular}{|c|c|c|c|}
\hline $\begin{array}{l}\text { time in } \\
\text { min. }\end{array}$ & $\begin{array}{l}\text { calcium } \\
\text { mval/1 }\end{array}$ & $\begin{array}{l}\text { alucose } \\
\mathrm{mg} \%\end{array}$ & $\begin{array}{l}\text { insulin } \\
\mu \mathrm{U} / \mathrm{ml}\end{array}$ \\
\hline 0 & $4.8 \pm .4$ & $91 \pm 11$ & $74 \pm 16$ \\
\hline 1 & $4.3 \pm .5$ & $280 \pm 63+$ & $69 \pm 12$ \\
\hline 3 & $4.6 \pm .5$ & $236 \pm 60+$ & $69 \pm 9$ \\
\hline
\end{tabular}

Table 1: Effect of $0.33 \mathrm{~g} / \mathrm{kg}$ glucose i.v.on serum calcium, glucose, and insul in in 5 newborns $(n=5)$. $+p<0.005$ compared to 0 min.

All other values are not siqnificant. (M \pm S.E.M.) 